\title{
PRECISION OF SIMPLIFIED MILK RECORDING FOR ZARAIBI GOATS
}

\author{
U.M. El-Saied, A.A. Raheem and I. Shaat
}

\author{
Animal Production Research Institute, Ministry of Agriculture and Land \\ Reclamation, Dokki, Giza, Egypt
}

\section{SUMMARY}

A total of 6604 test-day records belonging to 1651 lactations of 784 Egyptian Zaraibi goats were used to generate and evaluate several simplified milk yield recording plans based on the yield of a single monthly milking, adjusted or unadjusted for interval between milkings and for production level. Loss of precision associated with simplified designs was evaluated by comparing estimated lactation yields with actual milk yield, where the two daily milkings were recorded at daily intervals, and with the official A4 milk recording (monthly records of the two daily milkings) as reference methods. Actual milk yield included two traits: total suckled and milked milk (TSMM), i.e., milk yield from kidding to the end of lactation $(210 \mathrm{~d}$ milk yield) and total milked milk (TMM), i.e., post weaning milk yield for $120 \mathrm{~d}$. Breeding values from reference and simplified methods were predicted and compared. Simplified monthly plans were used to estimate both TSMM and TMM. The loss of precision in estimating TSMM was much lower (3.3-6.0\%) than that for TMM (12.3-18.3\%). Due to the essentially long suckling period during which peak lactation occurred for Zaraibi goats (almost $43 \%$ of the lactation period and $60 \%$ of milk yield), TSMM is better than TMM as a basis to evaluate simplified designs of milk yield recording. Therefore, TSMM is recommended to be used in genetic evaluation and managerial decisions. Most options with one daily milking every month were more accurate when the corresponding plan was based on, or started with, the a.m. milking. In most cases accuracy of estimation got worse by adjusting for interval between milkings or for production level. The design alternating a.m. and p.m. milkings, started with the a.m. milking and adjusted to the preceding interval between milkings gave the most satisfactory results with a slight advantage in precession $(\leq 2.6 \%)$ over other simplified methods. Product moment and rank correlations between breeding values predicted from actual and simplified designs were very high (0.972-0.997) indicating that any of the simplified methods can be used as a precise alternative to actual milk production for breeding decisions. For practical and economic reasons, the unadjusted alternating a.m. and p.m. milk recording, started with the a.m. milking is suggested for milk recording of Zaraibi goats.

Keywords: Milk recording, simplification, test-day records, breeding values, goats, Zaraibi.

Abbreviation Key: A4 = standard twice-a-day monthly recording, TSMM = total suckled and milked milk, TMM = total milked milk (post weaning milk yield for $120 \mathrm{~d}$ ).

Issued by The Egyptian Society of Animal Production 


\section{INTRODUCTION}

Zaraibi is the most pronounced dairy goat amongst the local breeds in Egypt. It is considered to be of high genetic potential as a dairy and prolific goat breed (AboulNaga et al., 1993). Both traits are considered to be of great economic importance for goat breeders. Zaraibi goat milk production averages $250 \mathrm{~kg}$ in an average lactation period of 210 days. Litter size ranges between 1 and 5 with an average of 2.1 kids (Raheem, 1998). Zaraibi kids are normally slaughtered at 6 months of age at approximately $30 \mathrm{~kg}$ of body weight (Abdel-Gawad et al., 2002). Due to the importance of Zaraibi goats as a prolific breed and its role in providing the domestic market with red meat, the normal husbandry includes a long kid suckling period of approximately three months to enhance health and survivalhood of the kids. The suckling period is followed by a milking period that begins after the kids are weaned and continues for four months approximately.

Milk recording systems, in general, include three main methods. The first concerns with the estimation of total suckled and milked milk (TSMM), i.e., the case of recording from kidding to the end of the lactation stage including both suckling and milking periods. The second method is the estimation of total milked milk (TMM), in which milk recording starts after weaning, i.e., during the milking period only and often called marketable milk. The last method, however, is based on the estimation of total milk yield (TMY: case of recording from kidding, without a suckling period). The objectives of milk recording include as an objective the estimation of milk yield for use in genetic improvement of the herd beside its use as a base for herd management decisions. Because of the high cost of milk recording relative to individual outputs for small ruminants, simplified procedures based on monthly recordings of only one daily milking (a.m. or p.m.) are of particular interest (Barillet et al., 1987 and Bouloc et al., 1991, Barillet and Astruc, 2004). A recent survey of the ICAR (Kopman et al., 2004) confirms that simplification of milk yield recording has widely spread among ICAR countries.

Previous research work has been carried out to evaluate the precision of simplified milk recording for dairy cows (Hargrove and Gilbert, 1984; Delorenzo and Wiggans, 1986; Anderson et al., 1989) and ewes (Gabiña et al., 1986; Gonzalo et al., 2003). However, there is a lack of information for dairy goats. In specific, no information is available on loss of precision associated with simplified recordings using actual milk yield on a comparative basis. In fact, the use of actual lactational milk yield would be more accurate than the official A4 method to evaluate simplified recording and would allow more reliable estimates of the loss of precision associated with simplified methods. More information is still needed on the use of TSMM or TMM as a base to evaluate simplified recording in dairy goats. This study generated various designs of simplifying milk recording to compare TSMM and TMM estimated from data generated from recording plans with estimates from both actual milk yield and A4 method, and assess the possibilities for their use for dairy goats.

\section{MATERIALS AND METHODS}

\section{Animals and herd management}

Data were provided from El-Serw Animal Production Research Station, Damietta Governorate, located in the North of the Nile Delta and belonging to the Animal Production Research Institute, Ministry of Agriculture and Land Reclamation, Egypt. 
Goats are housed in semi-roofed yards. Feeding allowances are calculated according to NRC (1981). The ration was offered twice daily at 08:00 $\mathrm{h}$ and 15:00 $\mathrm{h}$ and clean water and mineral supplementation were always available. Does were machine milked twice a day at 07:00 $\mathrm{h}$ and 17:00 $\mathrm{h}$.

Kids are naturally reared and kept with their mothers all the time except on the day of test. Milk recording during the suckling period (first $90 \mathrm{~d}$ postpartum) is practiced at irregular intervals, approximately at biweekly intervals, due to the difficulty to test all suckled does on the same day of test. Milk production of does was recorded daily after kidding until drying off. Morning milk yield was measured during the suckling period by isolating kids from their dams at $5.00 \mathrm{p} . \mathrm{m}$. then, weighed in the next day at 8.00 a.m., and allowed to suckle their dams until satisfaction, the increase in kids weight after each suckling was considered as milk consumption. Thereafter, the does were hand milked in order to estimate residual milk (stripped milk). The sum of suckled and stripped milk represents the quantity of the morning milk yield. Similar procedure was followed in estimating the evening milk production. The sum of morning and evening milk production represented daily milk production. Milk yield during the suckling period is calculated by multiplying the quantity of milk measured on the day of test by the interval in days between each two successive recording times.

After the suckling period, milk yield is recorded daily at 07:00 $\mathrm{h}$ and 17:00 $\mathrm{h}$ milkings. Milk yield is calculated after the suckling period to the end of lactation (TMM; post weaning milk yield for $120 \mathrm{~d}$, from the $4^{\text {th }}$ to the $7^{\text {th }}$ month post partum). TSMM (210 d milk yield) is calculated as the sum of milk yield during suckling and during milking periods. Four monthly test-day records (from the $4^{\text {th }}$ to the $7^{\text {th }}$ month postpartum) were taken on fixed dates; always at the evening milking of the $14^{\text {th }}$ day of the month and the morning of the following day.

\section{Data}

A total of 6604 test-day records belonging to 1651 lactations of 784 Zaraibi goats, daughters of 493 dams and 97 sires were available at monthly intervals from February 1996 to February 2005. The herd was divided into two groups, one to kid in February and another in October. Different recording plans were generated from the available data. These plans are summarized in Table (1).

The various plans of milk recording (Table 1) are categorized as follows:

1. Monthly recording of the two daily milkings (A4). Individual daily milk yield (Y) was calculated from the associated a.m. production (Pa.m.) and p.m. production (Pp.m.) as:

$\mathrm{Y}=$ Pa.m. + Pp.m.

2. Monthly recording of one fixed milking a day (AF):

2.1. Monthly recording of one fixed milking a day (AF) without adjustment: Individual daily milk yields were estimated from measurements on one milking as: $\mathrm{Y}$ $=2 \times$ Pa.m. or as: $\mathrm{Y}=2 \mathrm{x}$ Pp.m.

2.2. Monthly recording of one fixed milking a day (AF) adjusted for the entire herd production (AFAP): Individual daily milk yields were estimated as: $\mathrm{Y}=$ (Day's total production/Herd's production at a.m.) $\mathrm{x}$ Pa.m. or as: $\mathrm{Y}=$ (Day's total production/Herd's production at p.m.) x Pp.m. 
Table 1. Test-day recording plans during the milking period: reference and simplified plans

\begin{tabular}{|c|c|c|}
\hline Test day & $\begin{array}{l}\text { Periodically } \\
\text { (d) }\end{array}$ & $\begin{array}{c}\text { Recorded } \\
\text { milkings }\end{array}$ \\
\hline Actual milked yield ${ }^{1}$ & Daily & a.m. + p.m. \\
\hline $\mathrm{A} 4^{1}$ & 30 & a.m. + p.m. \\
\hline \multicolumn{3}{|c|}{$\begin{array}{l}\text { Monthly recording of one fixed milking a } \\
\text { day }(\mathbf{A F}) \text { : }\end{array}$} \\
\hline AF, p.m. & 30 & p.m. \\
\hline $\mathrm{AF}$, p.m., $\mathrm{AI}^{2}$ & 30 & p.m. \\
\hline AF, p.m., AP $^{3}$ & 30 & p.m. \\
\hline $\mathrm{AF}$, a.m. & 30 & a.m. \\
\hline $\mathrm{AF}$, a.m., $\mathrm{AI}^{2}$ & 30 & a.m. \\
\hline $\mathrm{AF}$, a.m., $\mathrm{AP}^{3}$ & 30 & a.m. \\
\hline \multicolumn{3}{|c|}{$\begin{array}{l}\text { Monthly recording alternating the a.m. and } \\
\text { p.m. milkings (AT): }\end{array}$} \\
\hline AT, p.m.-a.m. & 30 & Alternate p.m. ${ }^{4}$ - a.m. \\
\hline AT, p.m.-a.m., $\mathrm{AI}^{2}$ & 30 & Alternate p.m. ${ }^{4}$ - a.m. \\
\hline AT, p.m.-a.m., $\mathrm{AP}^{3}$ & 30 & Alternate p.m. ${ }^{4}$ - a.m. \\
\hline AT, a.m.-p.m. & 30 & Alternate a.m. ${ }^{4}$ - p.m. \\
\hline $\mathrm{AT}$, a.m.-p.m., $\mathrm{AI}^{2}$ & 30 & Alternate a.m. ${ }^{4}$ - p.m. \\
\hline AT, a.m.-p.m., $\mathrm{AP}^{3}$ & 30 & Alternate a.m. ${ }^{4}$ - p.m. \\
\hline
\end{tabular}

${ }^{1}$ Reference methods

${ }^{2}$ Adjusted for the interval preceding the current milking

${ }^{3}$ Adjusted for the entire herd production

${ }^{4}$ Milking the test day started with

2.3. Monthly recording of one fixed milking a day (AF) adjusted for the interval preceding the current milking (AFAI): Individual daily milk yields were estimated as: $\mathrm{Y}=(24 / 14) \times$ Pa.m. or as: $\mathrm{Y}=(24 / 10) \times$ Pp.m. Where, 14 and 10 are the p.m. $-\mathrm{a} . \mathrm{m}$. and a.m.-p.m. intervals in hours, respectively.

3. Monthly recording alternating the a.m. and p.m. milkings (AT):

3.1. Monthly recording alternating the a.m. and p.m. milkings without adjustment: Individual daily milk yields were estimated as: $\mathrm{Y}=(2 \mathrm{x}$ Pa.m. for even test-days $)+$ ( 2 x Pp.m. for odd test-days), where even test-days correspond to the $4^{\text {th }}$ and $6^{\text {th }}$ months postpartum and odd test-days correspond to the $5^{\text {th }}$ and $7^{\text {th }}$ months postpartum). In the second alternative individual daily milk yields were estimated as: $\mathrm{Y}=(2 \times$ Pp.m. for even test-days $)+(2 \times$ Pa.m. for odd test-days $)$.

3.2. Monthly recording alternating the a.m. and p.m. milkings adjusted for the entire herd production: Individual daily milk yields were estimated as: $\mathrm{Y}=$ (Day's total production/Herd's production at a.m.) x Pa.m. for even test-days + (Day's total production/Herd's production at p.m.) x Pp.m. for odd test-days. In the second alternative individual daily milk yields were estimated as: $\mathrm{Y}=$ (Day's total production/Herd's production at p.m.) x Pp.m. for even test-days + (Day's total production/Herd's production at a.m.) x Pa.m. for odd test-days.

3.3. Monthly recording alternating the a.m. and p.m. milkings adjusted for the interval preceding the current milking: Individual daily milk yields were estimated 
as: $\mathrm{Y}=((24 / 14) \times$ Pa.m. for even test-days $)+((24 / 10) \times$ Pp.m. for odd test-days $)$. In the second alternative individual daily milk yields were estimated as: $\mathrm{Y}=((24 / 10) \mathrm{X}$ Pp.m. for even test-days $)+((24 / 14) \times$ Pa.m. for odd test-days $)$.

Post weaning milk yield for $120 \mathrm{~d}$ (TMM) were estimated using the Fleischmann method, according to the following formula:

$$
Y=I_{1} \cdot Y_{1}+\sum_{i=2}^{i=4} I_{i} \frac{Y_{i}+Y_{i-1}}{2}
$$

Where $\mathrm{Y}=\mathrm{TMM} ; \mathrm{I}_{1}=$ interval between weaning date and first test-day after that $\left(4^{\text {th }}\right.$ month postpartum); $Y_{1}=$ milk yield of first test-day after weaning; $Y_{i}=$ milk yield of test-day $\mathrm{i}$; and $\mathrm{I}_{\mathrm{i}}=$ interval in days between each two consecutive test-days. TSMM, however, was calculated by adding TMM to milk yield during the suckling period for each doe.

\section{Statistical analysis}

Both TSMM (210 d) and TMM (post weaning milk yield for $120 \mathrm{~d}$ ) estimated for all simplified recording plans (Y) were compared with those from the actual and A4 reference methods $(\mathrm{X})$ by means of linear regression between $\mathrm{Y}$ and $\mathrm{X}$ according to the model $\mathrm{Y}=\mathrm{a}+\mathrm{bX}+\varepsilon$, where $\mathrm{a}=$ intercept, $\mathrm{b}=$ slope or coefficient of regression, and $\varepsilon=$ random error. Loss of precision of the simplified method was estimated as $1-$ $\mathrm{R}^{2}$ and expressed as a percentage. This analysis and all descriptive statistics were estimated by SAS (1998).

Breeding values were predicted using the PEST software by Groeneveld et al. (1990) through a multivariate trait repeatability animal model. The model included year-season of kidding (19 levels: ten years and two kidding seasons/year), litter size (single, double and triple and more kids), age of doe at kidding within parity (seven levels 1 to 6 and 7 and later parities) as fixed effects. Random effects included animal and permanent environmental effects. The heritability of actual TSMM was estimated using REML and the VCE 4.0 software (Groeneveld and García Cortés, 1998) with the same multiple-trait repeatability animal model. All known relationships among individuals were considered in the animal model.

\section{RESULTS AND DISCUSSION}

Milk yield during the suckling period (first $90 \mathrm{~d}$ postpartum) averaged $149.9 \mathrm{~kg}$ and represented almost $60 \%$ of milk production per lactation $(249.1 \mathrm{~kg})$. This considerable amount of milk was expected because the increasing phase of the lactation curve, peak milk yield of the breed and a part of the persistency of the curve take place within the suckling period. The results of the analysis of variance revealed that all fixed effects (year-season of kidding, litter size and age of doe within parity) contributed significantly $(P<0.001)$ to variation in all traits.

Averages and standard deviations for TSMM (210 d milk yield) together with loss of precision resulting due to simplified plans of recording and both actual milk yield and A4 design are shown in Table 2. Actual milk yield is much more precise than A4 to estimate the precision of simplified methods. As shown in Table 2, losses of precision between simplified designs and actual milk yield were higher (3.3-6.0\%) than between simplified designs and A4 method $(0.8-1.7 \%)$. The reason was 
probably that A4 method and all other simplified test-day designs were generated using the same method of estimation differing from actual milk yield.

Table 2. Arithmetic means of TSMM (210 d milk yield), standard deviations (SD), loss of precision $\left(1-R^{2}\right)$ and coefficients of regression (b) for the simplified test-day recordings on actual sucked and milked milk (ASMM) and on A4 method

\begin{tabular}{|c|c|c|c|c|c|c|}
\hline \multirow[t]{2}{*}{ Test day } & \multicolumn{2}{|c|}{ TSMM, kg } & \multicolumn{2}{|c|}{$\begin{array}{c}\text { With regard to } \\
\text { ASMM }\end{array}$} & \multicolumn{2}{|c|}{$\begin{array}{c}\text { With regard to } \\
\text { A4 }\end{array}$} \\
\hline & Mean & SD & $1-\mathbf{R}^{2}(\%)$ & $\mathbf{b}$ & $1-R^{2}(\%)$ & $\mathbf{b}$ \\
\hline ASMM & 245.1 & 64.9 & 0.0 & 1.00 & - & - \\
\hline A4 & 249.2 & 68.1 & 3.3 & 1.02 & 0.0 & 1.00 \\
\hline AF, p.m. & 244.3 & 67.4 & 4.7 & 1.01 & 1.3 & 0.98 \\
\hline AF, p.m., AI & 263.2 & 73.6 & 6.0 & 1.08 & 1.7 & 1.06 \\
\hline AF, p.m., AP & 249.0 & 68.9 & 4.9 & 1.03 & 1.3 & 1.00 \\
\hline AF, a.m. & 254.0 & 69.7 & 4.4 & 1.04 & 1.2 & 1.02 \\
\hline AF, a.m., AI & 238.9 & 64.9 & 3.4 & 0.98 & 1.1 & 0.96 \\
\hline $\mathrm{AF}, \mathrm{am}-\mathrm{AP}$ & 249.3 & 68.2 & 4.0 & 1.02 & 1.1 & 1.00 \\
\hline AT, p.m.-a.m. & 248.0 & 68.0 & 4.0 & 1.02 & 0.8 & 1.00 \\
\hline AT, p.m.-a.m., AI & 254.3 & 70.5 & 5.3 & 1.05 & 1.1 & 1.03 \\
\hline AT, p.m.-a.m., AP & 249.2 & 68.5 & 4.3 & 1.03 & 0.9 & 1.00 \\
\hline AT, a.m.-p.m. & 250.3 & 68.8 & 4.2 & 1.03 & 0.8 & 1.00 \\
\hline AT, a.m.-p.m., AI & 247.8 & 67.7 & 3.4 & 1.02 & 0.8 & 0.99 \\
\hline AT, a.m.-p.m., AP & 249.1 & 68.3 & 3.9 & 1.02 & 0.8 & 1.00 \\
\hline
\end{tabular}

Estimates of milk yield were in general of acceptable precise when compared with actual milk yield. Loss of precision through A4 method was 3.3\% when compared with actual milk yield (Table 2). Milk yield was estimated slightly more accurately with information from alternating a.m. and p.m milkings (loss of precision averaged $4.2 \%$ with regard to actual milk yield and $0.9 \%$ with regard to the A4 method) in comparison with monthly recording of one fixed milking a day (loss of precision averaged $4.6 \%$ with regard to actual milk yield and $1.0 \%$ with regard to the A4 method). When the two daily milkings are alternated, variation in a.m.-p.m. production would be compensated from one test day to another.

In general, estimating milk yield with information from the a.m. milking only was more accurate than from the p.m. milking (loss of precision ranged from $3.4 \%$ to $4.4 \%$, respectively with regard to actual milk yield and from $1.1 \%$ to $1.2 \%$ with regard to A4 method; Table 2). The corresponding figures using information from the p.m. milking only were $4.7 \%$ and $6.0 \%$, respectively with regard to actual milk yield and from $1.3 \%$ to $1.7 \%$ with regard to A4 method). Likewise, estimating milk yield through the monthly recording alternating a.m. and p.m. milkings was more accurate when recording was started with a.m. milking (loss of precision ranged from $3.4 \%$ to $4.2 \%$ with regard to actual milk yield and only $0.8 \%$ with regard to A4 method) than with p.m. (loss of precision ranged from $4.0 \%$ to $5.3 \%$ with regard to actual milk yield and from $0.8 \%$ to $1.1 \%$ with regard to A4 method).

Estimating milk yield by adjusting for milking interval or production level did not improve the accuracy of estimation in general (Table 2). In most cases, non- 
adjustment was slightly more precise than adjusting for either herd's production or the interval preceding milkings with regard to actual milk yield. Adjusting milk records to the interval preceding milkings slightly improved the accuracy of estimation in only two cases: the first when recording was based on a.m. milking only and the second in the alternating system started with the a.m. milking (Table 2).

When recording was started by the a.m. milking, adjusting milk records to the interval preceding milkings was the best choice (loss of precision was $3.4 \%$; Table 2 ) equal to the case of recording based on the a.m. milking, adjusting milk records to herd's production when both were compared with no adjustment. The a.m.-p.m. interval was shorter than the p.m.-a.m. interval (10 versus $14 \mathrm{~h})$ and prediction was slightly better from the a.m. milking than from the p.m. milking. These findings agreed with those reported for dairy goats (Bouloc et al., 1991), ewes (Gonzalo et al., 2003) and cows (Schaeffer and Rennie, 1976).

Among all the simplified plans, the alternative a.m.-p.m. scheme had the lowest value for loss of precision in comparison with both actual milk yield (3.4\%) and A4 method $(0.8 \%)$ followed by the fixed recording plan based on the a.m. milking, adjusting to herd's production. The corresponding figures for loss of precision for the former plan were $3.4 \%$ and $1.1 \%$, respectively. These results indicate greater accuracy when the simplified recordings based on or began with the a.m. milking rather than with the p.m. milking. Similar results were found for dairy ewes by Gabiña et al. (1986).

The final decision to recommend a simplified milk recording method should not only be based on the accuracy of the method but also on its simplicity, cost and applicability under field conditions and production system characteristics. A compromise between accuracy and simplicity should be made. Theoretically, the design alternating a.m. and p.m. milkings, started with the a.m. milking and adjusted to the preceding interval between milkings gave the most satisfactory results. However, the difference in precision between that method and other simplified methods was slight $(\leq 2.6 \%)$. From the practical point of view, the easiest method among the most precise methods is the desired one. In this context, the alternative recording without adjustment is precise enough for managerial decisions.

Table 3 shows averages and standard deviations for TMM (post weaning milk yield for $120 \mathrm{~d}$ ) together with loss of precision resulting from comparison between simplified plans and both actual milk yield and A4 design. Comparing loss of precision between Tables 2 and 3, it can be noticed that loss of precision was much higher in the case of TMM than TSMM. Loss of precision averaged $15.5 \%$ and $4.3 \%$, respectively for the two cases with regard to actual milk yield and $3.8 \%$ and $1.1 \%$, respectively with regard to the A4 design. Therefore, TSMM is better than TMM as a comparative base to evaluate simplified plans of milk yield recording and thus it is recommended to be used in genetic evaluation and managerial decisions. The essentially long suckling period $(90 \mathrm{~d}$ ) for the Zaraibi goats (almost $43 \%$ of the lactation period and $60 \%$ of TSMM), during which peak lactation occurred, may be the reason that TSMM is more accurate and better representing milk production of does than TMM as a comparative base to evaluate simplified plans of milk yield recording. Under the current management of Zaraibi goat herds, TMM can be considered as only a part of the total lactation (40\% of total milk yield and $57 \%$ of the lactation period) representing mainly the decreasing phase of the lactation curve. This is not the case in Europe for dairy ewes where shorter suckling periods are 
practiced (30 d) and TMM is more reliable (Gonzalo et al., 2003). Such system can not be applied with the Zaraibi goats as a prolific breed being used as dual purpose for both milk and meat. However, it is strongly recommended to improve the accuracy of estimation of milk yield during the suckling period in order to more accurately estimate TSMM. Suggested solutions may include: 1) to try to fix the time span between tests as much as possible; 2) to try to test the whole herd on one day of test or at least to increase the group size of does per day within each test and decrease the number of groups within each test as possible in order to facilitate calculations. Further detailed economic studies are strongly suggested to investigate this subject.

Table 3. Arithmetic means of TMM (post weaning milk yield for 120 d), standard deviations (SD), loss of precision $\left(1-\mathbf{R}^{2}\right)$ and coefficients of regression (b) for the simplified test-day recording on actual milked milk (AMM) and on A4 method

\begin{tabular}{|c|c|c|c|c|c|c|}
\hline \multirow[t]{2}{*}{ Test day } & \multicolumn{2}{|c|}{ TMM, kg } & \multicolumn{2}{|c|}{$\begin{array}{c}\text { With regard to } \\
\text { AMM }\end{array}$} & \multicolumn{2}{|c|}{ With regard to A4 } \\
\hline & Mean & SD & $1-\mathbf{R}^{2}(\%)$ & $\mathbf{b}$ & $1-\mathbf{R}^{2}(\%)$ & b \\
\hline AMM & 95.3 & 32.9 & 0.0 & - & - & - \\
\hline A4 & 99.3 & 37.5 & 12.3 & 1.07 & 0.0 & - \\
\hline AF, p.m. & 94.5 & 36.6 & 18.2 & 1.01 & 4.9 & 0.95 \\
\hline AF, p.m., AI & 113.3 & 43.9 & 18.2 & 1.21 & 4.9 & 1.14 \\
\hline AF, p.m., AP & 99.2 & 38.5 & 18.3 & 1.06 & 4.9 & 1.00 \\
\hline AF, a.m. & 104.1 & 40.2 & 14.4 & 1.13 & 4.1 & 1.05 \\
\hline AF, a.m., AI & 89.0 & 34.4 & 14.4 & 0.97 & 4.1 & 0.90 \\
\hline $\mathrm{AF}, \mathrm{am}-\mathrm{AP}$ & 99.4 & 38.4 & 14.4 & 1.08 & 4.1 & 1.00 \\
\hline AT, p.m.-a.m. & 98.1 & 37.3 & 15.2 & 1.04 & 3.1 & 0.98 \\
\hline AT, p.m.-a.m., AI & 104.4 & 40.6 & 18.1 & 1.12 & 3.8 & 1.06 \\
\hline AT, p.m.-a.m., AP & 99.4 & 38.0 & 15.9 & 1.06 & 3.2 & 1.00 \\
\hline AT, a.m.-p.m. & 100.5 & 38.9 & 14.7 & 1.09 & 2.9 & 1.02 \\
\hline AT, a.m.-p.m., AI & 97.9 & 37.3 & 12.7 & 1.06 & 2.9 & 0.98 \\
\hline AT, a.m.-p.m., AP & 99.2 & 38.3 & 14.1 & 1.08 & 2.8 & 1.00 \\
\hline
\end{tabular}

As can be seen in Table 3, estimates of milk yield were in general not precise when compared with actual milk yield including the A4 method. Equally to the case of TSMM, TMM was estimated slightly more accurately with information from alternating a.m. and p.m milkings. In general, estimating TMM with information from the a.m. milking only was more accurate than from the p.m. milking. Similarly, estimating TMM through the monthly alternate recording was more accurate when recording was started with the a.m. milking. Estimating TMM by adjusting for milking interval or production level did not improve the accuracy of estimation. Among all the simplified plans, the alternative a.m.-p.m. scheme had the lowest value for loss of precision in comparison with actual milk yield (12.7\%).

Table 4 presents product moment and rank correlation coefficients among breeding values predicted for $210 \mathrm{~d}$ milk yield from the two reference methods (actual suckled and milked milk and A4 method) and other simplified test-day designs. As can be seen in the table, both types of correlations were extremely high between actual and simplified design (0.972-0.987) and were very close to each other. Correlations were also high and close to each other between A4 method and simplified design (0.992-0.997). From the practical point of view, there is no 
difference between actual and all simplified methods in the context of predicting breeding values and accordingly to the subsequent selection and culling decisions. Genetic selection is expected to have a good response as heritability of actual TSMM in this study was estimated as $0.34( \pm 0.01)$. Based on these results and those for loss of precision associated with simplified designs, it is recommended to use the plan of alternating a.m. and p.m. milkings every month without adjustment, starting with the a.m. milking as a simplified milk recording for Zaraibi goats.

Table 4. Product moment $(P M)$ and rank (R) correlation coefficients among breeding values predicted for milk yield in $210 \mathrm{~d}$ from reference methods and other simplified test-day designs

\begin{tabular}{lcccc}
\hline \multirow{2}{*}{$\begin{array}{l}\text { Simplified } \\
\text { method }\end{array}$} & test-day & \multicolumn{2}{c}{ With regard to actual milk yield } & \multicolumn{2}{c}{ With regard to A4 method } \\
\cline { 2 - 5 } & $(\mathrm{PM})$ & $(\mathrm{R})$ & $(\mathrm{PM})$ & $(\mathrm{R})$ \\
\hline A4 & 0.987 & 0.985 & - & - \\
AF, p.m. & 0.983 & 0.980 & 0.994 & 0.993 \\
AF, p.m., AI & 0.979 & 0.975 & 0.994 & 0.992 \\
AF, p.m., AP & 0.972 & 0.979 & 0.995 & 0.993 \\
AF, a.m. & 0.981 & 0.977 & 0.995 & 0.994 \\
AF, a.m., AI & 0.984 & 0.982 & 0.996 & 0.995 \\
AF, a.m., AP & 0.982 & 0.979 & 0.996 & 0.994 \\
AT, p.m.-a.m. & 0.984 & 0.981 & 0.996 & 0.995 \\
AT, p.m.-a.m., AI & 0.980 & 0.976 & 0.995 & 0.994 \\
AT, p.m.-a.m., AP & 0.983 & 0.980 & 0.996 & 0.995 \\
AT, a.m.-p.m. & 0.982 & 0.979 & 0.997 & 0.996 \\
AT, a.m.-p.m., AI & 0.985 & 0.983 & 0.997 & 0.996 \\
AT, a.m.-p.m., AP & 0.983 & 0.981 & 0.997 & 0.996 \\
\hline
\end{tabular}

\section{CONCLUSION}

Loss of precision was much higher in the case of TMM than with TSMM indicating a better use of TSMM as a comparative base to evaluate simplified plans and to be used for genetic evaluation and managerial decisions. The plan of alternating a.m. and p.m. milkings, started with the a.m. milking and adjusted to the preceding interval between milkings gave the most satisfactory results with a slight advantage in precession $(\leq 2.6 \%)$ over other simplified methods. Product moment and rank correlations between breeding values predicted from actual and simplified designs were very high and very close in all cases indicating that any of the simplified methods can be used as a precise alternative to actual milk production for breeding decisions. Based on the results of this study, and for practical and economic reasons, the design alternating a.m. and p.m. milkings, unadjusted and started with the a.m. milking is suggested for milk recording of Zaraibi goats.

\section{ACKNOWLEDGEMENT}

The authors are grateful to Prof. Dr. L. Fernando de la Fuente, Department of Animal Production, University of León, Spain for his helpful advice during the design of the work and aid during the statistical analysis. 


\section{REFERENCES}

Abdel-Gawad, E.I., G. M. Maharim, F.F. Abou Ammo and F.A. Ibrahim, 2002. Effect of yeast culture (Lacto-Sacc) supplementation on growth, some body parameters and carcass quality in goats. Egyptian J. Appl. Sci., 17(7): 375-388.

Aboul-Naga, A.M., M.B. Aboul-Ela, M.K. Ibrahim and M.R. Mousa, 1993. Oestrous performance in Egyptian Nubian (Zaraibi) goats. J. Agric. Sci. Mansoura Univ., 18: 2262-2266.

Anderson, S.M., I.L. Mao and J.L. Gill, 1989. Effect of frequency and spacing of sampling on accuracy and precision of estimating total lactation milk yield and characteristics of the lactation curve. J. Dairy Sci., 72: 2387-2394.

Barillet, F. and J.M. Astruc, 2004. Current challenge for milk recording in dairy sheep and goats: the simplification of milk sampling design for chemical composition and somatic cell counts of milk. Performance recording of animals: state of the art 2004. Proceedings of the $34^{\text {th }}$ Biennial Session of ICAR, Sousse, Tunisia, $28^{\text {th }}$ May- $3^{\text {rd }}$ June, 2004. EAAP publication number 113, Wageningen, 97-102.

Barillet, F., N. Boichard, D. Bouloc, D. Gabiña, A. Piacere, M. Roussely and J.P. Sigwald, 1987. Précision et mise en oeuvre dans les espéces ovine et caprine de méthodes simplifiées de contrôle laitier adaptées a leur finalité. [Accuracy and development of simplified sampling procedures with regard to the aim of milk recording in dairy sheep and goats]. In Proceedings of the $38^{\text {th }}$ Annual Meeting European Association for Animal Production, p. 1014. Sheep and Goat Commission, Lisbon, Portugal.

Bouloc, N., F. Barillet, D. Boichard, J.P. Sigwald and G. Bridoux, 1991. Étude des possibilités d'allègement du contrôle laitier officiel chez les caprins. [Studies of possibilities of simplification of official test-day in goats.] Annales de Zootechnie. 40: 125-139.

Delorenzo, M.A. and G.R. Wiggans, 1986. Factors for estimating daily yield of milk, fat, and protein from a single milking for herds milked twice a day. J. Dairy Sci., 69: 2386-2394.

Fuertes, J.A., C. Gonzalo, J.A. Carriedo and F. San Primitivo, 1998. Parameters of test day milk yield and milk components for dairy sheep. J. Dairy Sci.,81:13001307.

Gabiña, D., E. Urarte and J. Arranz, 1986. Métodos de simplificación. de control lechero. cuantitativo. Aplicación a las razas ovinas del País Vasco. [Test-day simplification methods. Application to ewe breeds of the Basque Country.] Investigación Agraria: Producción Sanidad Animal 1: 159-170.

Gonzalo, C., M.H. Othmane, J.A. Fuertes, L.F. De La Fuente and F. San Primitivo, 2003. Losses of precision associated with simplified designs of milk recording for dairy ewes. J. Dairy Res., 70: 441-444.

Groeneveld, E., and L.A. García Cortés, 1998. VCE 4.0, a (co)variance component package for frequentists and Bayesians. Proc. $6^{\text {th }}$ World Congr. Genet. Appl. Livest. Prod., Armidale, Australia. XXVII: 455-456.

Groeneveld, E., M. Kovac, and T. Wang, 1990. PEST - a general purpose BLUP package for Prediction and Estimation in multivariate linear models. In $4^{\text {th }}$ World Congress On Genetics Applied To Livestock Production. Edinburgh, Number XIII, pages 488-491. 
Hargrove, G.L. and G.R. Gilbert, 1984. Differences in morning and evening sample milkings and adjustment to daily weights and percents. J. Dairy Sci., 67: 194-200.

International Committee for Animal Recording, 1992. Regulations for milk recording in dairy sheep. Group of experts for milk recording in dairy sheep. European Association for Animal Production, Rome, Italy.

Kopman, D., A. Cividini, M. Simcic and M. Klopcic, 2004. Report of the WG on milk recording of goats. Proceedings of the $34^{\text {th }}$ Biennial Session of ICAR, Sousse, Tunisia, $28^{\text {th }}$ May- $3^{\text {rd }}$ June, 2004.

NRC, 1981. Nutrient requirements of domestic animals. Nutrient requirements of domestic goats. National Research Council, Washington D.C.

Raheem, A.A., 1998. Genetic studies on Zaraibi goats. Ph.D. Thesis, Fac. of Agric, Ain Shams, Univ., Egypt. pp 41.

SAS User's Guide: Statistics, Release 6.12.1998. SAS Inst., Inc., Cary, NC.

Schaeffer, L.R. and J.C. Rennie, 1976. AM-PM testing for estimating lactation yield. Canadian J. Anim. Sci., 56: 9-15. 


\section{دقة نظم تسجيل انتاج اللبن المبسطة فى الماعز الزرايبى أسامة محمد السعيد، عبد الفتاح عبد الحكيم عبد الرحيم، ايهاب شعت}

معطة بحوث الإتتاج الحيوانس، وزارة الززراعة و ستصلاح الأراضى، الدقى، جيزه، مصر

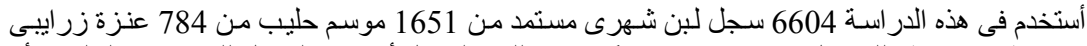

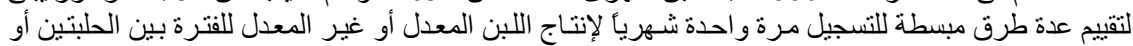

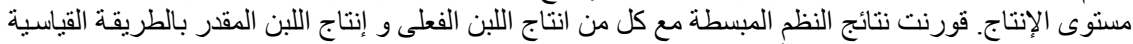

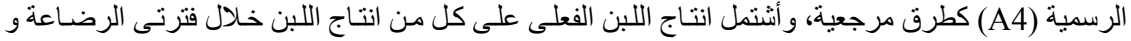

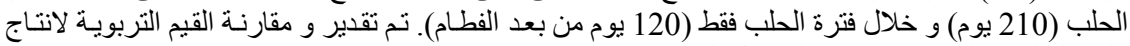

اللبن الفعلى و المقدر من طرق التسجيل المبسطة.

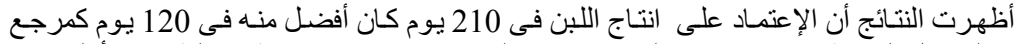

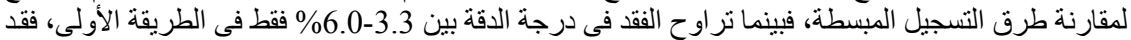

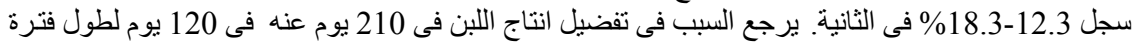

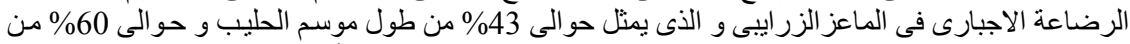

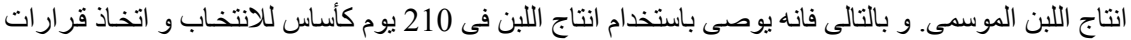

كان الإعتماد على حلبة الصباح فقط أو البدء بها فى طريقة التنجيل التبادلية أفضل من حلبة العساء

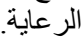

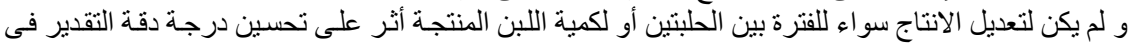

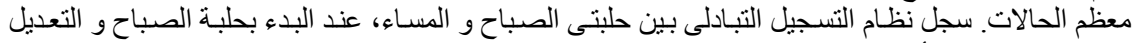

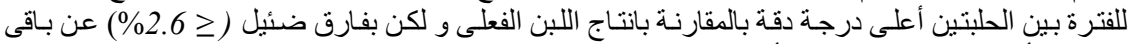

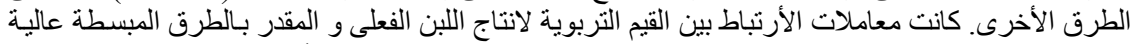

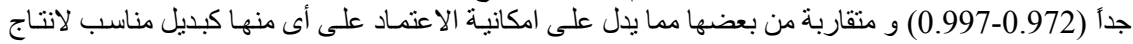

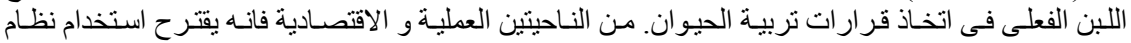

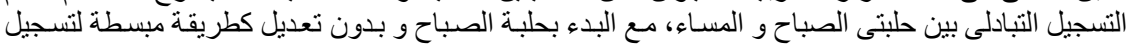

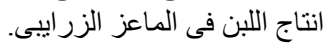

